\title{
Correspondence
}

\section{The effects of indomethacin on serum gastrin concentrations}

Sir,

It is known that some patients with rheumatoid arthritis have a raised serum gastrin concentration. ${ }^{1}$ However, it has been difficult to separate the effects of the disease itself from those due to drug administration in the causation of raised gastrin levels. We have recently studied the effects of indomethacin on serum gastrin concentrations in both volunteers and patients.

Six healthy male volunteers were fasted overnight and 2 blood samples for basal serum gastrin levels were taken. Following a standard protein meal, further blood samples were taken every 10 minutes for the first hour and every 15 minutes for the second hour. Indomethacin (50 $\mathrm{mg}$ ) or matching placebo were given by mouth in random order, half an hour before the first blood sample was taken, in 2 separate studies. In 4 of the 6 volunteers after 8 days on $25 \mathrm{mg}$ q.d.s. indomethacin, basal and post protein diet gastrin were also determined, and indomethacin plasma concentrations were measured 2 to 3 hours after the last morning dose. In 25 patients with rheumatoid arthritis, treated in the long term with $25 \mathrm{mg}$ t.d.s. indomethacin, a single blood sample for gastrin and indomethacin was taken 2 to 3 hours after breakfast.

Gastrin was measured in serum by the method of Dockray and Taylor ${ }^{2}$ and plasma indomethacin by gas liquid chromatography. ${ }^{3}$

The results are shown in Table 1 and indicate that indomethacin caused no significant differences in the gastrin response to a standard test meal. In 24 of the patients serum gastrin concentrations were in the normal range of $15-45 \mathrm{pmol} / \mathrm{l}$. One patient had serum gastrin concentrations in excess of $600 \mathrm{pmol} / \mathrm{l}$, and she was later shown to have achlorhydria.

Plasma indomethacin concentrations were $415 \pm 156$ $\mathrm{ng} / \mathrm{ml}$ in the volunteers at the end of the gastrin study and $326 \pm 81 \mathrm{ng} / \mathrm{ml}$ in the patients. These results are in the usual therapeutic range and indicate compliance with the therapeutic regimen. ${ }^{4}$

Table 1 Mean basal gastrin values (pmol/l) and peak increments in serum gastrin after standard protein meal mean $\pm S E$

\begin{tabular}{lllll}
\hline & Placebo & \multicolumn{3}{l}{ Indomethacin } \\
\cline { 2 - 5 } & $\begin{array}{l}\text { Basal } \\
\text { gastrin }\end{array}$ & $\begin{array}{l}\text { Peak } \\
\text { increment }\end{array}$ & $\begin{array}{l}\text { Basal } \\
\text { gastrin }\end{array}$ & $\begin{array}{l}\text { Peak } \\
\text { increment }\end{array}$ \\
\hline $\begin{array}{l}\text { Single dose } \\
\text { volunteer }\end{array}$ & $13 \cdot 1 \pm 1.9$ & $45.0 \pm 11.9$ & $14 \cdot 0 \pm 3.1$ & $43 \cdot 8 \pm 13.6$ \\
$\begin{array}{l}\text { Multiple } \\
\text { dose } \\
\text { volunteer }\end{array}$ & $13 \cdot 2 \pm 3.0$ & $52.0 \pm 17.5$ & $9.7 \pm 3.0$ & $31.2 \pm 8.5$ \\
\hline
\end{tabular}

Our results show that indomethacin has no effect on serum gastrin concentrations, and it is unlikely, therefore,, that the indigestion seen with indomethacin is mediatedo via a rise in serum gastrin. Our studies are in agreement with those of Rooney et al., ${ }^{5}$ performed without the use of a standard protein meal, and the uncontrolled obser- vations of Cutarelli et al., ${ }^{6}$ using phenylbutazone.

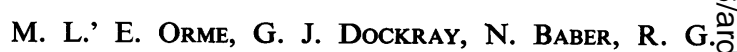
Sibeon, L. D. HALliday AND T. R. LitTLER Department of Pharmacology and Therapeutics and University of Liverpool, and Regional Rheumatology Unit,,${ }_{\infty}^{\text {Physiology, }}$ Leasowe, Wirral.d่

\section{References}

1 Rooney P J, Vince J, Kennedy A C, et al. Hypergastrinaemia in rheumatoid arthritis: disease or iatrogenesis. Br Med J 1973; 2: 752-3.

2 Dockray G J, Taylor I. Heptadecapeptide gastrin:ठ measurement in blood by specific radioimmunoassay. $\mathbb{D}$ Gastroenterology 1976; 71: 971-7.

3 Sibeon R, Baber N, Chan K, Baty D, Orme M L'옹. A quantitative gas liquid chromatographic method the determination of indomethacin in biological flur J Chromatogr 1978; 153: 189-94.

4 Baber N, Halliday L D C, Vandenheuvel W J A, et al. study of indomethacin in rheumatoid arthritis: clinical effects, pharmacokinetics, and platelet studies in responders and non responders. Ann Rheum Dis 1979; 38: 128-37.

5 Rooney P J, Grennan D M, Sturrock R D, Brooks P M, $\overrightarrow{\vec{O}}$ Dick W C. Serum immunoreactive gastrin: specificity for rheumatoid arthritis, bimodulity of distribution and failure of effect of anti-inflammatory drugs. Ann Rheum? Dis 1976; 35: 40-5.

- Cutarelli G, Caldera R, Bierti L. Effect of anti-inflam-ஹِ matory agents on serum gastrin concentrations. Ann $\overline{2}$ Rheum Dis 1977; 36: 97.

\section{Pyogenic arthritis presenting as a ruptured popliteal cyst}

Sir,

I read with interest the paper by Drs Stewart, Swinson, $N$ and Hardinge ${ }^{1}$ but should like to draw your attention to the erroneous statement that rupture of a popliteal $N$ cyst is a frequent complication of rheumatoid arthritis. $N$ This statement is frequently repeated in literature more $\sigma$ from habit than belief, I suspect. Enlargement of the cysts in the popliteal fossa is extremely common in rheumatoid arthritis, but they very rarely rupture. It is $\cong$ the knee joint itself which is the source of the leak. This, if repeated, leads to the development of a calf cyst, $\frac{T}{T}$ which is probably what Baker was referring to, and is of quite different origin to the popliteal cyst, which is 